\title{
Rare association between cystic fibrosis, Chiari I malformation, and hydrocephalus in a baby: a case report and review of the literature
}

Akash J Patel, Viraj H Raol and Andrew Jea*

\begin{abstract}
Introduction: Cystic fibrosis, an epithelial cell transport disorder caused by mutations of the cystic fibrosis transmembrane conductance regulator gene, is not generally associated with malformations of the central nervous system. We review eight previously published reports detailing an infrequent association between cystic fibrosis and Chiari I malformation.

Case presentation: To the best of our knowledge, our report describes only the ninth case of a baby presenting with a new diagnosis of cystic fibrosis and Chiari I malformation, in this case in a 10-month-old, full-term Caucasian baby boy from the United States of America. Neurosurgical consultation was obtained for associated developmental delay, macrocephaly, bulging anterior fontanel, and papilledema. An MRI scan demonstrated an extensive Chiari I malformation with effacement of the fourth ventricle, obliteration of the outlets of the fourth ventricle and triventricular hydrocephalus without aqueductal stenosis. Our patient was taken to the operating room for ventriculoperitoneal shunt placement.

Conclusions: It is possible that the cystic fibrosis transmembrane conductance regulator gene may play a previously unrecognized role in central nervous system development; alternatively, this central nervous system abnormality may have been acquired due to constant valsalva from recurrent coughing or wheezing or metabolic and electrolyte imbalances that occur characteristically in cystic fibrosis.
\end{abstract}

\section{Introduction}

Cystic fibrosis (CF) is a disorder in which transepithelial ion transport affects fluid secretion in exocrine glands and the epithelium of the respiratory, gastrointestinal, and reproductive tracts [1]. Although developmental abnormalities of the male genital tract are commonly associated with CF, malformations of other organ systems, particularly the central nervous system (CNS), are rarely associated with the disorder.

Chiari I malformation, defined by herniation of the cerebellar tonsils below the foramen magnum, is associated with hydrocephalus in $7 \%$ to $10 \%$ of cases $[2,3]$. Hydrocephalus often originates in the fourth ventricular outflow obstruction. An association between Chiari I malformation and cystic fibrosis has only been reported in the literature three times[4-6]. In the eight

\footnotetext{
* Correspondence: ajea@bcm.edu

Division of Pediatric Neurosurgery, Texas Children's Hospital, Department of Neurosurgery, Baylor College of Medicine, Houston, TX, USA
}

previously-reported patients with Chiari malformation, six patients had a known CF diagnosis, and two had an autopsy CF diagnosis. Here, we add the case of a ninth patient to the literature; a 10-month-old baby with a diagnosis of CF and associated Chiari I malformation and hydrocephalus. We also discuss the unusual association of these conditions.

\section{Case presentation}

A 10-month-old, full-term Caucasian baby boy from the United States of America with a history of multiple respiratory infections, persistent cough, and greasy stools since birth, presented to our facility with failure to thrive and a one-week history of emesis. Our patient had a positive sweat chloride test result, confirming a new diagnosis of CF. Upon physical examination, we discovered he had macrocephaly with a head circumference in the 98th percentile, splaying of the sutures, and a bulging fontanel. A

\section{() Biomed Central}


fundoscopic examination demonstrated papilledema. The remainder of his physical examination was unremarkable.

Imaging studies demonstrated Triventricular hydrocephalus and severe Chiari I malformation with $2.2 \mathrm{~cm}$ of cerebellar tonsillar herniation to the C3 level (Figure 1). Our patient did not have Chiari malformation symptoms at this time and was without signs of spinal cord compression or cerebellar or brainstem dysfunction. Therefore, we elected to treat the hydrocephalus first and followed our patient closely for the development of a problematic Chiari malformation.

Our patient was brought into the operating room for ventriculoperitoneal shunt (VPS) placement. The opening pressure was noted to be approximately $25 \mathrm{~cm} \mathrm{H}_{2} \mathrm{O}$ upon cannulation of the ventricular system. The rest of the operation proceeded in standard fashion.

Our patient did well after surgery; he had no continued signs and symptoms of increased intracranial pressure and was discharged home the following day. At one-year follow-up with the Cystic Fibrosis Clinic and the Neurosurgery Service, our patient was continuing to do well with no signs or symptoms of increased intracranial pressure or problematic Chiari malformation.

\section{Discussion}

\section{CF and Chiari I malformation}

$\mathrm{CF}$ is an autosomal recessive disorder characterized by abnormal chloride conduction across epithelial membranes. It is the most common lethal genetic disease in the Caucasian population, with an incidence of one in 1500 to one in 4000 live births [1].

An association between CF and Chiari malformation has been previously reported in eight patients (Table 1) [4-6]. Rusakow et al. described a seven-year-old Hispanic girl with cystic fibrosis from homozygous delta F508

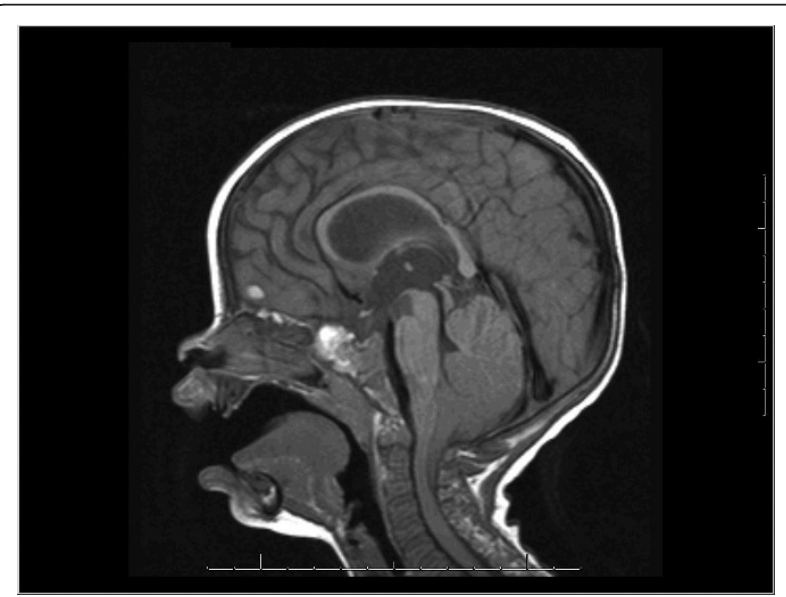

Figure 1 Mid-sagittal T1 weighted MRI of the brain shows tonsillar herniation to the level of $\mathbf{C 3}$. There is effacement of the fourth ventricle and Triventricular hydrocephalus. mutations who had cervicothoracic syringomyelia and a Chiari I malformation [6].

Needleman et al. described five patients who were known to have CF and were diagnosed with Chiari malformation after developing various neurological symptoms [4]. There were four males and one female ranging from 10 months to 18 years old. One of the patients was homozygous for the delta F508 mutation, while the others were heterozygous. In two patients, the second mutations could not be identified, while the remaining patients showed G542X and W1282X as their second mutation, respectively. The authors concluded that when patients with cystic fibrosis have unexplained neurological issues, Chiari I malformation is likely.

Rakheja et al. described two babies with a known diagnosis of Chiari I malformation and hydrocephalus; however, the CF diagnosis was not made until after death [5]. At presentation, the two patients, one boy and one girl, were four months and eight months old, respectively. One patient underwent Chiari decompression followed by shunt placement; the other underwent VPS placement as the initial treatment. The fourmonth-old boy died a month after surgery from acute bronchopneumonia leading to Pseudomonas aeruginosa sepsis. The eight-month-old girl died a year after surgery from increased intracranial pressure and possible shunt obstruction.

The mechanism of an association between cystic fibrosis and Chiari I malformation is unknown. It does not appear that the association is due to a specific type of cystic fibrosis transmembrane conductance regulator (CFTR) mutation as several different point mutations have been described in patients with both conditions [5]. It is possible that the CFTR gene plays an unrecognized role in CNS development. CFTR mRNA and protein expression have been identified in the developing human hypothalamus where the protein may be involved in neuropeptide vesicle trafficking $[7,8]$. Children with newly-diagnosed CF have transiently-elevated intracranial pressure which is thought to be due to either vitamin A deficiency, a response to treatment of their malnutrition [9], or intermittent valsalva from persistent, chronic wheezing or coughing [10,11]. Vitamin A also affects the development of this CNS/skeletal abnormality, as it induces abnormal cranial vault development and herniation of the cerebellum in hamster embryos [12].

\section{Chiari I malformation and hydrocephalus}

In 1891, Hans Chiari was the first to describe the cerebellar tonsils descending below the foramen magnum [13]. However, the origin and pathophysiology of this condition remains poorly understood. Generally considered a congenital anomaly, some reports suggest that 
Table 1 Previous reports of cystic fibrosis (CF) and Chiari malformation

\begin{tabular}{|c|c|c|c|c|c|c|c|}
\hline Reference & Age & Sex & $\begin{array}{l}\text { Presenting signs and } \\
\text { symptoms }\end{array}$ & $\begin{array}{l}\text { Radiologic findings } \\
\text { (extent of Chiari, } \pm \text { aqueductal } \\
\text { stenosis, } \pm \text { hydrocephalus) }\end{array}$ & Treatment & $\begin{array}{l}\text { Follow- } \\
\text { up }\end{array}$ & Outcome \\
\hline [10] & $\begin{array}{l}10 \\
\text { months }\end{array}$ & M & Swallowing dysfunction & Not reported & $\begin{array}{l}\text { Chiari } \\
\text { decompression }\end{array}$ & $\begin{array}{l}\text { Not } \\
\text { reported }\end{array}$ & $\begin{array}{l}\text { Resolution of } \\
\text { symptoms }\end{array}$ \\
\hline [10] & $\begin{array}{l}18 \\
\text { years }\end{array}$ & M & Syncope & Not reported & $\begin{array}{l}\text { Chiari } \\
\text { decompression }\end{array}$ & $\begin{array}{l}\text { Not } \\
\text { reported }\end{array}$ & $\begin{array}{l}\text { Resolution of } \\
\text { symptoms }\end{array}$ \\
\hline [10] & $\begin{array}{l}17 \\
\text { years }\end{array}$ & $F$ & Numbness of extremities & Not reported & $\begin{array}{l}\text { Chiari } \\
\text { decompression }\end{array}$ & $\begin{array}{l}\text { Not } \\
\text { reported }\end{array}$ & $\begin{array}{l}\text { Resolution of } \\
\text { symptoms }\end{array}$ \\
\hline [10] & $\begin{array}{l}\text { three } \\
\text { years }\end{array}$ & M & Recurrent vomiting & Not reported & None & $\begin{array}{l}\text { Not } \\
\text { reported }\end{array}$ & Symptoms unresolved \\
\hline [10] & $\begin{array}{l}17 \\
\text { years }\end{array}$ & M & Persistent headache & Not reported & $\begin{array}{l}\text { Chiari } \\
\text { decompression }\end{array}$ & $\begin{array}{l}\text { Not } \\
\text { reported }\end{array}$ & $\begin{array}{l}\text { Resolution of } \\
\text { symptoms }\end{array}$ \\
\hline [13] & $\begin{array}{l}\text { four } \\
\text { months }\end{array}$ & M & Failure to thrive & $\begin{array}{l}\text { Aqueductal stenosis; } \\
\text { hydrocephalus }\end{array}$ & VP shunt & $\begin{array}{l}\text { three } \\
\text { months }\end{array}$ & Death from sepsis \\
\hline [13] & $\begin{array}{l}\text { eight } \\
\text { months }\end{array}$ & $\mathrm{F}$ & $\begin{array}{l}\text { Failure to thrive, } \\
\text { nystagmus }\end{array}$ & $\begin{array}{l}\text { Tonsillar herniation with } \\
\text { hydrocephalus }\end{array}$ & $\begin{array}{l}\text { Chiari } \\
\text { decompression and } \\
\text { VP shunt }\end{array}$ & $\begin{array}{l}\text { one } \\
\text { year }\end{array}$ & $\begin{array}{l}\text { Shunt malfunction and } \\
\text { cerebral herniation }\end{array}$ \\
\hline [15] & $\begin{array}{l}\text { eight } \\
\text { years }\end{array}$ & $\mathrm{F}$ & $\begin{array}{l}\text { Thoracic scoliosis; gait } \\
\text { instability; hand wasting }\end{array}$ & $\begin{array}{l}\text { Chiari I with thoracic scoliosis and } \\
\text { cervicothoracic syrinx }\end{array}$ & $\begin{array}{l}\text { Chiari } \\
\text { decompression }\end{array}$ & $\begin{array}{l}\text { two } \\
\text { months }\end{array}$ & $\begin{array}{l}\text { Resolution of } \\
\text { symptoms }\end{array}$ \\
\hline $\begin{array}{l}\text { Present } \\
\text { report }\end{array}$ & $\begin{array}{l}10 \\
\text { months }\end{array}$ & M & Vomiting & $\begin{array}{l}2.2 \mathrm{~cm} \text { of herniation; aqueductal } \\
\text { stenosis; hydrocephalus }\end{array}$ & VP shunt & $\begin{array}{l}\text { one } \\
\text { month }\end{array}$ & $\begin{array}{l}\text { Resolution of } \\
\text { symptoms }\end{array}$ \\
\hline
\end{tabular}

$\mathrm{VP}=$ ventriculoperitoneal.

Chiari I malformation may be a sequelae of intracranial hypertension [14]. In his 1891 monograph, Chiari originally surmised that hydrocephalus pushed the cerebellar tonsils into the foramen magnum. But overt hydrocephalus is only reported in $7 \%$ to $10 \%$ of patients with symptomatic Chiari I malformation [15]. However, others have asserted that Chiari I malformation is a developmental anomaly of the posterior fossa with subsequent arachnoid adhesions, thought to be due to repeated trauma [16]. Therefore, any associated hydrocephalus may be due to fourth ventricular outflow obstruction [17]. It is possible that persistent coughing in CF could lead to arachnoid adhesions and altered CSF dynamics, resulting in hydrocephalus. This remains to be studied.

Krayenbuhl reported that 20 of 22 patients with symptomatic Chiari I malformation who were initially treated with ventriculoatrial shunt placement experienced symptom improvement [16]. Endoscopic third ventriculostomy may be an alternative to ventricular shunt placement for hydrocephalus associated with Chiari I malformation [15].

\section{Conclusions}

In summary, we describe the case of a 10-month-old baby boy with a new diagnosis of CF and, later, Chiari malformation and hydrocephalus after presenting with developmental delay, macrocephaly, bulging anterior fontanel, and papilledema. We hypothesize that the CF precipitated the Chiari malformation although the mechanism is unclear. The extensive Chiari malformation then caused obstruction at the fourth ventricle outlets and resulted in hydrocephalus. Because of the young age of our patient, we elected to treat him with a VPS. His long-term clinical outcome remains to be determined.

\section{Consent}

Written informed consent was obtained from the patient's next-of-kin for publication of this case report and any accompanying images. A copy of the written consent is available for review by the Editor-in-Chief of this journal.

\section{Acknowledgements}

The authors would like to recognize Lily Chun for her editorial assistance in the production of this manuscript.

\section{Authors' contributions}

AJP and VHR were major contributors in the writing and editing of the manuscript. AJ was a major contributor in the interpretation and analysis of the data from our patient, and contributed to the design, writing, and editing of the manuscript. All authors read and approved the final manuscript.

\section{Competing interests}

The authors declare that they have no competing interests.

Received: 22 December 2010 Accepted: 12 August 2011

Published: 12 August 2011

\section{References}

1. Schofield D, Cotran RS: Diseases of infancy and childhood. In Robbins Pathologic Basis of Disease.. 6 edition. Edited by: Cotran RS, Kumar V, Collins T. Philadelphia, PA: WB Saunders; 1999:477-481. 
2. Milhorat TH, Chou MW, Trinidad EM, Kula RW, Mandell M, Wolpert C, Speer MC: Chiari I malformation redefined: clinical and radiographic findings for 364 symptomatic patients. Neurosurgery 1999, 44:1005-1017.

3. Tubbs RS, McGirt MJ, Oakes WJ: Surgical experience in 130 pediatric patients with Chiari I malformations. J Neurosurg 2003, 99:291-296.

4. Needleman JP, Panitch HB, Bierbrauer KS, Schidlow DV: Chiari type I malformation in children and adolescents with cystic fibrosis. Pediatr Pulmonol 2000, 30:490-492.

5. Rakheja D, Xu Y, Burns DK, Veltkamp DL, Margraf LR: Cystic fibrosis and Chiari type I malformation: autopsy study of two infants with a rare association. Pediatr Dev Pathol 2003, 6:88-93.

6. Rusakow LS, Guarin M, Lyon RM, Splaingard ML: Syringomyelia and chiari malformation presenting as scoliosis in cystic fibrosis. Pediatr Pulmonol 1995, 19:317-318.

7. Mulberg AE, Weyler RT, Altschuler SM, Hyde TM: Cystic fibrosis transmembrane conductance regulator expression in human hypothalamus. Neuroreport 1998, 9:141-144.

8. Weyler RT, Yurko-Mauro KA, Rubenstein R, Kollen WJ, Reenstra W, Altschuler SM, Egan M, Mulberg AE: CFTR is functionally active in GnRHexpressing GT1-7 hypothalamic neurons. Am J Physiol 1999, 277:C563-571.

9. Roach ES, Sinal SH: Initial treatment of cystic fibrosis. Frequency of transient bulging fontanel. Clin Pediatr (Phila) 1989, 28:371-373.

10. Dure LS, Percy AK, Cheek WR, Laurent JP: Chiari type I malformation in children. J Pediatr 1989, 115:573-576.

11. Pascual J, Iglesias F, Oterino A, Vazquez-Barquero A, Berciano J: Cough, exertional, and sexual headaches: an analysis of 72 benign and symptomatic cases. Neurology 1996, 46:1520-1524.

12. Marin-Padilla M, Marin-Padilla T-M: Morphogenesis of experimentally induced Arnold-Chiari malformation. J Neurol Sci 1981, 50:29-55.

13. Chiari $\mathrm{H}$ : Concerning alterations in the cerebellum resulting from cerebral hydrocephalus. 1891. Pediatr Neurosci 1987, 13:3-8.

14. Payner TD, Prenger E, Berger TS, Crone KR: Acquired Chiari malformations: incidence, diagnosis, and management. Neurosurgery 1994, 34:429-434.

15. Banerji NK, Millar JH: Chiari malformation presenting in adult life. Its relationship to syringomyelia. Brain 1974, 97:157-168.

16. Krayenbuhl $\mathrm{H}$ : Evaluation of the different surgical approaches in the treatment of syringomyelia. Clin Neurol Neurosurg 1975, 77:111-128.

17. Hayhurst C, Osman-Farah J, Das K, Mallucci C: Initial management of hydrocephalus associated with Chiari malformation type I-syringomyelia complex via endoscopic third ventriculostomy: an outcome analysis. J Neurosurg 2008, 108:1211-1214.

doi:10.1186/1752-1947-5-366

Cite this article as: Patel et al:: Rare association between cystic fibrosis, Chiari I malformation, and hydrocephalus in a baby: a case report and review of the literature. Journal of Medical Case Reports 2011 5:366.

\section{Submit your next manuscript to BioMed Central and take full advantage of:}

- Convenient online submission

- Thorough peer review

- No space constraints or color figure charges

- Immediate publication on acceptance

- Inclusion in PubMed, CAS, Scopus and Google Scholar

- Research which is freely available for redistribution

Submit your manuscript at www.biomedcentral.com/submit
Biomed Central 